\title{
Creative survival as subversion
}

\section{Solidarities and creative tactics against "conditions of death" ${ }^{1}$}

I n the DRC, the exercise and consolidation of state authority does not necessarily imply social transformation or a real commitment of the state to impose itself but, rather, the management of state absences and state presences through a plurality of authorities. Still, the patterns of coercion and extraction that have followed from the 20 years of conflict, with the different state-making and peacebuilding processes, determine the conditions for the continuation of poverty on the ground. Poverty has a long and complex historical legacy. Nonetheless, the process of producing state authority is part and parcel of processes of production, distribution and institutionalisation of social hierarchy. ${ }^{2}$ Kankwenda notes that predation in the DRC, or, as he calls it, "predatocracy' is 'as old as the country' (2005: 10 and 17). As such, the strategies of resistance against the impact of war and peacebuilding on livelihoods are inscribed in a long historical trajectory. Some would argue that these strategies are characteristic of the material relationship between states and societies, or even of the natural struggle against poverty (Ouendji 2009; Latouche 2007; Ward 1973). ${ }^{3}$ Although a similar argument should be made of discursive and violent practices so far observed, creative survival figures prominently as an example of how patterns of resistance are recontextualised alongside changes in political and economic circumstances.

Peacebuilding in this sense represents a contemporary snapshot of a historical process in which political, economic and cultural relations connect the local to the global. Whether resistance is exercised discursively, violently or, as will be explored in this chapter, as a form of survival, it is conditioned by the way authority is asserted along the axis of state absence and presence. Nonetheless, in this interstice, solidarity, and not just coercion and extraction, is an important element of the everyday political landscape.

Creativity, as the art of la débrouille, ${ }^{4}$ is defined here as the use of imagination, solidarity and reciprocity to produce anything that allows or improves survival. Although a rumba song may have captured the concept better, 
Figure 6.1 is also illustrative of the ways in which creativity provides everyday needs. ${ }^{5}$ It is a broom made from needle-like palm leaves held together by a tomato can. The making of this broom is the fruit of a myriad of monetary, symbolic and reciprocal exchanges. The final product is testimony to how Congolese creativity facilitates survival and that this is a collective project. ${ }^{6}$ This creativity is applied to the delivery of all sorts of services (food security, health, education, conflict resolution, and even national army and police provisioning). By taking control of these services, subordinate classes are simultaneously articulating modes of political authority and social organisation in a way that denies, mitigates, 'de-totalises' and provides alternatives to state authority (Bayart 1983: 119). ${ }^{7}$

This is not necessarily an attack, or a direct denial. Rather, it is a selfregarding activity, a form of aikido, that subverts forms of extraction by enacting

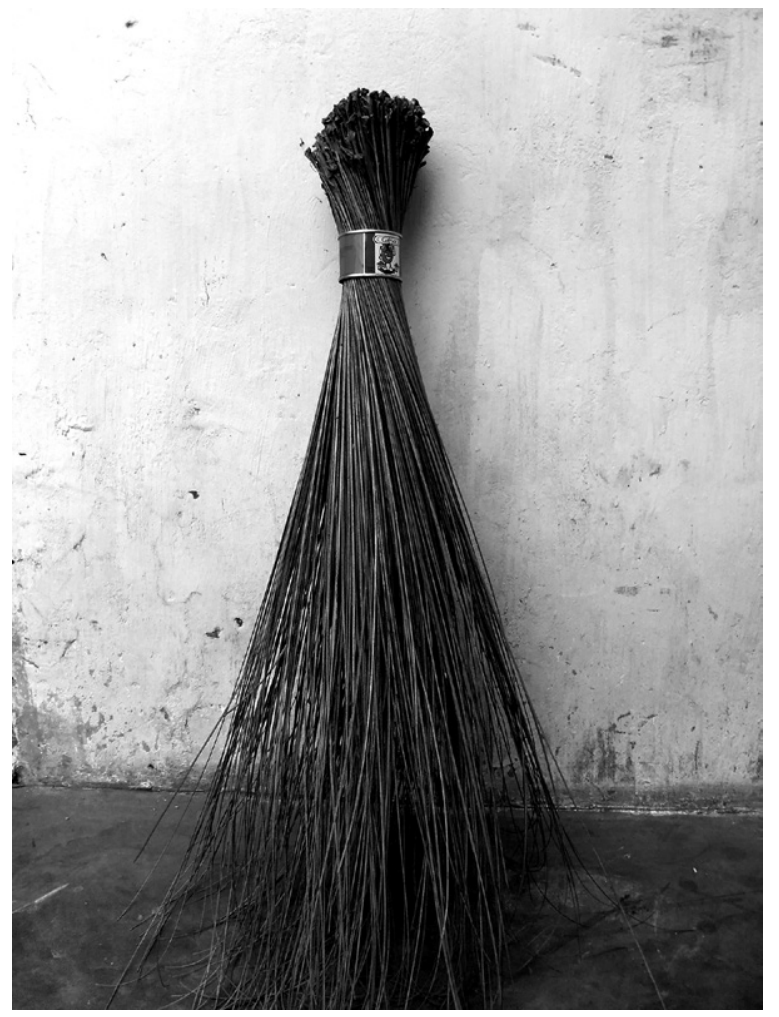

Figure 6.1 Home-made broom, photo taken June 2010, private dwelling, Yolo Nord, Kinshasa 
channels of re-appropriation. This re-appropriation provokes denial of extractive claims and facilitates the mitigation of the effects of domination. Within these practices of survival there are different practices and grades in the visibility of intent. For instance, while tax evasion or defending landownership through armed groups could be seen as a more direct claim-regarding form of resistance, non-violent self-help tactics of land seizure, negotiating the terms of military rule and social service and infrastructure provision could all be seen as self-regarding activities that subvert the effects of poverty, appropriation and authoritarianism. ${ }^{8}$ Revisiting Certeau's language, they are tactics that follow self-logics, they redirect wealth, re-appropriate it and defend it, subverting the logic of power. This interpretation is nonetheless contested. Everyday survival is also the site of structural violence, racketeering and mutual manipulations. The analysis of survival as resistance does not tell a romantic story but only explores the dynamics of resistance that rely on survival strategies as they attempt to appease or evade extraction.

This chapter is structured in four sections around the topics just mentioned. It first addresses these critiques as a way of analysing how the framework applies to survival. The following three sections then offer examples that illustrate different aspects of peacebuilding and resistance practices, starting with tax evasion and practices against elite land appropriation. ${ }^{9}$ Then follows a section illustrating the mitigation of the authoritarian nature of military rule through negotiation. This has to do with the military approach against armed groups as part of the political compromises with the FDLR, CNDP and Rwanda, and as a palliative to state absence. The chapter finishes with a section examining various examples of social service provision.

All these examples illustrate that surviving and mitigating the effects of dispossession are simultaneously a way to provide self-management and to rearticulate the social and political space. They reaffirm mechanisms of selfreliance and assert alternative political agendas. In all these areas, although it might not be explicitly stated, women take a central role, being the main service providers (Demobilised Mai Mai Padiri Combatant 1 2009; Peasant Union Member (no. 151) 2010; Yoka 2009: 11). The note on gender division should not be seen, especially after the preceding chapter, as a portrayal of warmongering men and caring women (Elshtain 1998). Far from establishing an image of women as 'peace-makers' and men as 'war-mongers', these divisions need to be seen as part of the imperative of a broader war context, determining labour roles through gender roles. It should also be noted that the examples discussed here of taxation, land distribution, negotiating military rule and social service provision, are all complex areas from which one could generate volumes of analysis. They have been chosen as illustrations of the dynamics between peacebuilding, state-making and resistance as they pertain to the sphere of livelihoods and material extraction. 


\section{Appropriation and extraction in the interstice of state presences and absences}

The reliance for survival on the débrouille has been a feature of Congolese history. The response to the 'delinquency' of this relatively absent state, as Kankwenda puts it, has been 'the emergence of an active and dynamic civil society, organised to take control of everyday survival, education, health, neighbourhood security, etc' (2005: 176). 'People being in charge' has a dual political value as social services and as political organisation (Barrios 2010: 6-9). For Mac Gaffey, for example, 'through the second economy, the citizenry may not only evade civil obligations but also express resistance to the state and to the class which controls it' (1991: 10). It follows that with the humanitarian crisis of the different wars in the DRC, the economy has once again relied on people's capacity for survival, reflecting the tension between necessity and resistance.

Survival has been seen as an effect of governmentality, signalling accommodation, not resistance, to a successfully imposed neoliberal agenda (Chabal 2009). ${ }^{10}$ Some have also argued that the relative absence of the state facilitates the creation of mechanisms of domination where the state and the effects of a particular political economy transcend private life (Chabal 2009; Hibou 2011b; see also: Meddeb 2011). Subjection, or at least, negotiation, is henceforth the key for surviving domination, but may not be seen as a form of resistance.

The work of Chabal exemplifies this view. He argues, firstly, that the state may not be able to do what it is mandated to do but it is still vigorous enough to keep a check on what is being done informally' (2009: 132). As a result, the state keeps a degree of control on the ground and maintains informal networks of power linked to state agents and bureaucrats. Secondly, Chabal argues that subordinate classes, by providing all sorts of social services, from security to electricity, and hospitals to rubbish management, are actually involved in a form of state extortion. 'Civil servants', he argues, 'prey on those who cannot afford to resist them: police harass ordinary people; nurses demand bribes; teachers require payment; the providers of official paperwork (ID cards, passports, market licences, etc.) sell their "good offices"' (Chabal 2009: 151).

Chabal identifies what has been noted in previous chapters, that the capacity of peace strategies to claim success is the capacity of subordinate classes to absorb their negative consequences. Leaving people to 'fend for themselves', whether it is rubbish collection, dealing with armed groups or sustaining the national army, can be viewed, within the context of the DRC, as a mode of extortion only benefiting those who would otherwise be responsible for dealing with these things. However, the problem with Chabal's arguments is that he does not afford agency to the political choices that subordinate classes make. This is not to say that people opt to be exploited, but to observe just this factor is to ignore the daily strategies of resistance to exploitation and the capacity of subordinate classes to exercise control over their circumstances. ${ }^{11}$ Whereas 
predatory strategies are seen in many state-residual services, self-provision helps to placate poverty, violence and war, and to mitigate the extraction of labour, land and taxes.

These strategies also create mutual obligations where ideals concerning what authorities should be doing provide a measure of legitimacy. Chabal himself states that:

[a]t the heart of the politics of belonging and partaking[,] relations of proximity and reciprocity provide the foundations upon which rulers and ruled, elite and populace, relate to each other within and across communities [and] notions of ethics and morality are based on the honouring of relations of social exchange and on how these relations influence the nature and conduct of politics on the continent. (2009: 136)

Therefore 'bartering' puts authorities and subordinate classes on a more equal footing. It grants non-elites a space for subverting the relationship by imposing on elites the requirement to negotiate. In all of this, as mentioned before, there is an element of exploitation and abandonment. As a resident of a Butembo neighbourhood put it: 'if we have to wait for the state, nothing gets done' (Neighbourhood Representative of 10 houses 2010). This self-management and selfprovision palliates the effects of domination, identifying alternative political agendas of food security, land and political participation. The examples provided in this chapter are not exhaustive; they illustrate instances of everyday survival where the elements of denial, mitigation and the advancing of subordinates' own agendas are present.

\section{Confronting extraction, subverting distribution}

State authority assertion and consolidation is done through the levying of taxes and the transfer and allocation of property rights. Despite its claim to bring order and stability, statebuilding brings with it a predatory effect, which is seen in the areas of land property management. In the DRC, since land belongs to the state by law, its allocation can be arbitrary, yet remaining within the law; land links state administrators to multiple state institutions and private elites. Similarly, taxes are not only a tool for state financing but also a survival strategy for public servants. ${ }^{12}$ Contradictorily, the resilience of customary and collective land administration, in addition to the fact that the state cannot efficiently raise taxes, offers an insight into how everyday creative survival denies and mitigates the impact that taxation and elite land distribution has on peasants' livelihoods (African Development Bank 2012: 4).

$\operatorname{Tax}$

Popular classes see tax collection as illegitimate. Whether in a formalised or informalised way, there is widespread concern that taxes are paid to enrich the 
pockets of the politicians. ${ }^{13}$ There is nothing unusual about this; the same patterns of discourses and tax evasion could be found worldwide. However, in the DRC, taxes not reaching the state take on an important dimension. Those that are collected on the ground generate revenues, and this is illustrated by the dynamics in which tax collection and tax evasion take place. The tax revenue in the DRC was 13.5 per cent of total GDP in 2010 (as opposed to for instance the 25.1 per cent of the UK) (World Bank 2012b, 2015). According to the World Bank, in all countries, generally, 1 per cent of registered tax-payers provide 70 per cent of the tax revenue (International Finance Corporation 2009: 17). Thus, while non-elite tax contributions to the state treasury are marginal or non-existent, they make up the salary of state-representatives on the ground.

Still, the way taxation works also means that there is widespread tax avoidance. ${ }^{14}$ In a focus group in Butembo (North Kivu), five out of six participants confirmed that they did not pay their taxes, firstly because the tax officer rarely came to their houses, and secondly because they felt that they did not owe anything to the state (Focus Group Butembo Residents 2010). The chief of this neighbourhood stated that before they paid their taxes, the state had to fix the streets (only three major roads were asphalted) (Walikomba 2010). In informal conversations, many residents stated their refusal to pay their taxes if they were not going to get anything back from them. Interestingly, the idealised version of the state works as a tax avoidance strategy: if the state does not work for them, people will not pay the state its dues.

This was a constant in all places where fieldwork was undertaken. Conflict around tax seemed to be especially prevalent around small commerce, where tax officers are more present. In Goma, in a small survey carried out with street sellers, all participants confirmed that they had found ways to avoid taxation. ${ }^{15}$ This included hiding merchandise, packing and leaving, and alternating selling days. In the central market at Baraka (South Kivu), sellers complained about the variety and cost of the taxes. They said that the benefit they receive is too low and the taxes are too high. As a result, they have invented mechanisms for tax evasion (Baraka Market Sellers 2010). For instance, people selling the same products tend to gather together in the same place. They keep checking whether a tax officer might be coming. If an officer arrives, several sellers of the same product will go away, while one remains. This individual tells the officer that all the products are hers so that the tax paid is substantially lower than if each person had to pay for their products separately. The result is a mutual reticence. Neither the tax officers nor the taxpayers are happy with the tax system, but they cohabit as a kind of a stalemate. This does not mean a lack of conflict. On the contrary, there is a constant 'toing and froing', which, in the context of war, entails negotiation, but also armed confrontation.

As with the workshops organised to desolidarise the population from armed groups, tax payment has its own 'sensitisation' workshops. For example, a Civil 
Society (SOCICO) representative in Masisi was asked by the Government to carry out seminars to 'demand people to pay their taxes'; but, as he said, 'that didn't pass well through their ears' (President of Civil Society Masisi Centre 2011). A representative of the Itinerant Traders Association in Bunyakiri spoke about the arbitrariness with which taxes were charged. In an exemplary instance of negotiation, he indicated that often "when there is a tax that traders see as unfair or that they cannot pay, the association speaks to the inspector or the authorities so that traders are relieved of the payment' (Bikanaba 2010). This cautious negotiation style was reflected in the taxation campaign started by the provincial government of South Kivu. The message on a poster, displayed in one of the poorest neighbourhoods in Bukavu, gently asked: 'Dear tax-payer, pay your taxes and duties in order to aid your provincial Government to finance the 5 pledges and other projects of development. ${ }^{16}$ As Mkandawire has shown, unpaid taxes are a sign of the weakness of the state and the success of resistance in many African countries (2008: 119-20). The result is a mutual 'arm's length' distance. The Government makes the people responsible for the lack of development, while people are not willing to pay taxes until they see the Government working for development.

However, negotiation and coercion go hand in hand. The state seeks alternative ways to finance its own presence and support elite networks, including both threats and the imposition of penalties, including prison (Mukendi 2010). The state shares the power to levy taxation with armed groups, the army and the police. This kind of taxation is often negotiated but, if it is not accepted, it is done at gunpoint. The use or the threat of violence makes this taxation difficult to evade and further spurs armed contestation. As an example, Table 6.1 shows the taxes extracted by the FARDC and Amani Leo forces.

Table 6.1 only shows estimates, from multiplying the extraction observed in one day by the 30 days in a month. Although these are not exact figures, extortion by FARDC and Amani Leo troops has been widely reported (Global Witness 2009: 27-30, 2010b: 8; UN Group of Experts 2010b: p. 3 and para. 177; 2011: paras 301-2). However, it would be limited to conclude that the above supports Chabal's arguments about successful domination. These activities should not be looked at from the perspective of whether the state has been 'successful' in extracting taxes and whether resistance has been 'successful' in avoiding them. Rather, both of these practices should be seen as ongoing dynamics. For statemaking, these dynamics entail negotiation and sharing fiscal authority; for resistance they mean a denial of taxes and legitimacy to the state.

\section{Land}

To a large extent, all of the above regarding taxation applies also to land. However, land has a special symbolic and historical meaning. Changes in its use and property have a direct impact not just on revenue and political authority, but 
Table 6.1 FARDC extortion at checkpoints in Kabare and Kasha

\begin{tabular}{|c|c|c|c|c|c|c|}
\hline No. & Checkpoint & Area & Troops & $\begin{array}{l}\begin{array}{l}\text { Period of } \\
\text { observation }\end{array} \\
\end{array}$ & $\begin{array}{l}\text { Daily takings } \\
\text { (USD) }\end{array}$ & $\begin{array}{l}\text { Estimated monthly } \\
\text { takings (USD) }\end{array}$ \\
\hline 1 & Cibingu & \multirow{7}{*}{$\begin{array}{l}\text { Axe } \\
\text { Kabare-Nindja }\end{array}$} & Amani Leo & 13.4 .10 & 69 & 2,055 \\
\hline 2 & Citende Ludaha & & Amani Leo & 14.4.10 & 102 & 3,069 \\
\hline 3 & Kamukenge & & Amani Leo: 31st & \multirow{5}{*}{$\begin{array}{l}8-10 \\
\& 12-14.4 .10\end{array}$} & \multirow[t]{5}{*}{101} & \multirow[t]{5}{*}{3,036} \\
\hline 4 & Mulembo & & Amani Leo: 31st & & & \\
\hline 5 & Lushandja & & Amani Leo: 31st & & & \\
\hline 6 & Chez Nshembe & & Amani Leo: 31st & & & \\
\hline 7 & Biranga & & 10th Military Region & & & \\
\hline 8 & Mbalaza & Kasha & 10th MR: Bagira camp & $23-26.4 .10$ & 24 & 719 \\
\hline 9 & Rugondo I & Kasha & 10th MR: artillery & 23-26.4.10 & 48 & 1,427 \\
\hline 10 & Rugondo II & Kasha & 10th MR: artillery & 23-26.4.10 & 53 & 1,600 \\
\hline 11 & Mogo & Cirunga & 10th MR: Bagira camp & $15-17.4 .10$ & 55 & 1,637 \\
\hline 12 & Cidaho & Cirunga & 10th MR: Bagira camp & $12-14.4 .10$ & 36 & 1,094 \\
\hline 13 & Kaiwaira & Bugobe-Ludaha & 10th MR: Bagira camp & $12-15.4 .10$ & 22 & 660 \\
\hline 14 & Chez Chiyumpa & & 10th MR: Bagira camp & $12-15.4 .10$ & 28 & 839 \\
\hline \multirow[t]{2}{*}{15} & Buhanga & & 10th MR: Bagira camp & $12-15.4 .10$ & 69 & 2,068 \\
\hline & & & & & Total & 18,203 \\
\hline
\end{tabular}

Source: Oxfam International (2009: 5) 
also on the social order and identity attached to it. As such, the conflict over land is one not only of livelihoods but also of political projects. One project is based on community control, participation in political representation and dignified living; another concerns increasing land privatisation and concentration; yet other concerns state security and managing military and elite conflicts. These have been underlined by a process of militarisation, as war has acted as a conveyor belt between statebuilding and changes in land tenure. Land seizure and allocation in the DRC have become militarised both through direct occupation by armed groups and by the military response these seizures have prompted. As with the operations of armed groups, wars over land, and subsequent lack of access to land, have caused massive flight. ${ }^{17}$ Even if the land becomes empty, it still fulfils a series of statebuilding purposes: production of revenue through its sale, allocation or transfer to politicians, entrepreneurs or MNCs and the production of shared authority. Similarly, even if armed groups occupy land, if they are sufficiently powerful, they are likely to join elite and statebuilding networks. ${ }^{18}$

Creativity has subverted elite-land distribution in three ways: as survival against deteriorating livelihoods, as cooperation for production and distribution and as a form of negotiation with elites. ${ }^{19}$ These practices do not necessarily demonstrate a victory against elite-land redistribution, but they subvert the logic of appropriation, mitigating its effects and serving non-elite agendas. The effect is also a denial of legitimacy to elite claims, the detotalisation of coercion, the imposition of negotiation and the projection of political alternatives. Networks of proximity and kin, cooperative schemes, relying on solidarity and reciprocity, are often used as the 'workers' wig', in Certeau's terms. They are the foundation for maintaining and recreating forms of political authority and self-organisation. There is a caveat to this affirmation: as the conflict over land has followed ethnic lines, one may argue that the elite/non-elite distinction is inadequate. This is partly true. However, the elite/non-elite division identifies the political and economic status linked to land tenure, even if social mobility makes these identities fluid. ${ }^{20}$ As such, without making permanent statements about who belongs where on the basis of class or ethnic identity, this division gains currency because it illustrates the patterns in which those who hold the power to grant land access are resisted by those who do not.

In a study on land tenure, conflict and household land-use strategies in the territories of Masisi, Lubero (North Kivu) and Walungu (South Kivu), Vlassenroot (2006) identifies several mechanisms of survival within a context of increasing dispossession and food insecurity. They go from collective responses such as shared production and cooperative membership to individual methods such as crop theft and militia membership. Table 6.2 summarises the research and findings.

Many of these strategies are present in the activities of the League of Women Peasants Cooperative (LOFEPACO). ${ }^{21}$ This is a federation of peasant 
Table 6.2 'Food constraints and household strategies'

\begin{tabular}{|c|c|c|}
\hline Constraints to food production & $\begin{array}{l}\text { Constraints to food } \\
\text { access }\end{array}$ & Household strategies \\
\hline $\begin{array}{l}\text { - Shifts in land tenure systems: } \\
\text { - from a system of relative } \\
\text { equality, proximity and } \\
\text { mutual dependency based } \\
\text { on customary chiefs to a } \\
\text { system of alliances based } \\
\text { on proximity to } \\
\text { Kinshasa's authorities } \\
\text { - collective tenure } \\
\text { increasingly privatised } \\
\text { and expropriated to large } \\
\text { ranches } \\
\text { - Limited access to land } \\
\text { - Crop restrictions on rental } \\
\text { land } \\
\text { - Reduction of plot sizes } \\
\text { - Conflicts over land } \\
\text { ownership } \\
\text { - Loss of livestock } \\
\text { - Other conditions: } \\
\text { • Decrease of land fertility } \\
\text { due to over-exploitation } \\
\text { • Demographic pressure } \\
\text { • Presence of armed } \\
\text { elements } \\
\text { • Pillaging of harvests }\end{array}$ & $\begin{array}{l}\text { - Reduction of } \\
\text { purchasing power } \\
\text { - Limited availability } \\
\text { of food } \\
\text { - Increase in the } \\
\text { amount and } \\
\text { number of taxes } \\
\text { - Limited access to } \\
\text { markets due to } \\
\text { insecurity } \\
\text { - Absence of } \\
\text { cooperatives that } \\
\text { protect merchants } \\
\text { - Lack of organisation } \\
\text { - Pillaging of stocks } \\
\text { - Degradation of road } \\
\text { network } \\
\text { - Destruction of } \\
\text { market } \\
\text { infrastructures } \\
\text { - Disappearance of } \\
\text { microcredit systems }\end{array}$ & $\begin{array}{l}\text { - Cultivation of small } \\
\text { plots in wetlands } \\
\text { - Shift from monoculture } \\
\text { to polyculture } \\
\text { - Adaptation of crop } \\
\text { diversification to (lack } \\
\text { of) tenure security } \\
\text { - Shift from agriculture to } \\
\text { petty trade } \\
\text { - Shifts in food } \\
\text { consumption patterns } \\
\text { - Harvest and } \\
\text { consumption of } \\
\text { immature crops } \\
\text { - Cash for work } \\
\text { - Joining of farmers' } \\
\text { associations } \\
\text { - Cultivation on shared } \\
\text { plots } \\
\text { - Migration to urban } \\
\text { centres or mining sites } \\
\text { - Joining of local militias } \\
\text { - Theft of crops }\end{array}$ \\
\hline
\end{tabular}

Source: Adapted and edited from Vlassenroot (2006: 3. Clarifications on land tenure changes from pp. 6-7)

organisations for the protection of peasant interests, but with a special regard for women's issues (most organisations integrated in LOFEPACO are women only). According to Clarisse Ngemulo, LOFEPACO's activity animator, the creation of these organisations and the federation responded to a need to provide women with a space to deal with their specific problems. These problems include a sense of disempowerment, inequality and marginalisation. In the Hira culture in particular, women have inferior cultural status, ${ }^{22}$ and around the year 2000 they decided to create a federation to reinforce the strength and effectiveness of other organisations in the empowering of women and peasants. ${ }^{23}$ The league facilitates exchanges and training in different domains, 
including government lobbying. What is striking is that in the middle of one of the worst periods of armed conflict they felt that the struggle they had started and the campaigning tools the cooperative was granting them became even more meaningful. Not only did women feel like the main targets of war, but they also considered that part of the solution to war relied on solving the problems of poverty, inequality, corruption and certain customary traditions that kept women disadvantaged.

As such, the federation constituted an economic solution, a funding mechanism against the effects of war, a campaigning tool and a vehicle for political and social change. ${ }^{24}$ Its activities included the creation of a credit cooperative, assuring food security, creating a seed bank and exchanging products and skills training. The women-only spaces promoted discussion on empowerment, selfesteem, leadership, awareness of land-tenure rights, customary rules and sexism, and what they called 'listening spaces'. These were spaces where women who had been raped could be heard by other women; this has been reinforced by INGO funding and training and has now developed into a psychological and economic support for survivors of sexual violence. ${ }^{25}$ They have organised sit-ins to demand the de-militarisation of certain areas like Mangango and Beni. They have also been successful in allowing many widows to access land titles. This has been achieved through campaigning and accompanying claimants to the territorial administrator office.

These activities demonstrate an associative tendency when addressing needs and engaging in political claims. Most importantly, they demonstrate that the constraints imposed by the political context do not make peasants lower their political aspirations; instead these become imperative. Of the six peasant cooperatives interviewed for this research, all emphasised that the end of war should bring well-being, development, education, equality and political participation. ${ }^{26}$ For instance, a representative of the Union of Peasant Cooperatives of North Kivu (UCOOPANOKI), a cooperative of farms and cultivators, said that the main problems they faced were the appropriation of land by politicians, big landowners and MNCs, as well as the incursions by armed groups stealing their crops. ${ }^{27}$ Their aspirations were stated in terms of land access, security and fair prices to assure life in dignity (Batenda 2010). ${ }^{28}$

Likewise, in Bukavu, the UPDI (Union Paysanne pour le Developpement Integral) was born in 1994 out of peasant members feeling disempowered and marginalised from INGO development projects (UPDI Representative 2010). Although land seizures and changes in land tenure had been in place already under Mobutu, the war has accentuated this. Peasants feel that they are victims of all parties, including politicians, armed groups and MNCs, and marginalised in decision-making. They see themselves as an essential part of development, being at the heart of agricultural production. Significantly, the activities of the cooperatives mentioned above included a project of food security and a project 
of social change. The peasants all claimed a need for empowerment and resolution of land conflict.

\section{Subverting logics}

Extraction through taxation and elite-land distribution illustrates the mechanisms whereby statebuilding and resistance could be seen simultaneously in direct conflict, as in conditions of mutual reticence. The models of private ownership pursued by the DRC Government and international agencies, added to the favoured model of extraction whereby precarious artisanal and militarised mining serves large corporations but not necessarily local communities, poses a threat to some of the core subsistence mechanisms that the peasantry has traditionally relied on (Global Witness 2009: 59-69). Tax levy, although not a source of state income, serves other political and military purposes that foster the presence of state authority. In this context, resistance delegitimises authority, reduces its extractive impact and imposes negotiation. More so, resistance produces self-organising mechanisms that resonate with non-elite aspirations for social justice and alternative forms of political authority. It is argued that these subversive practices follow self-regarding logics and operate as self-help mechanisms for re-appropriation and well-being; they are a form of resistance to the modes of accumulation. This raises the question of the relationship between these forms of resistance and peacebuilding. Peacebuilding produces externalities that are felt by the civilian population on the ground. An additional use of survival strategies and cooperative schemes is to tame the effects of the authoritarian nature of the army. This is a direct implication of having a strategy that privileges the needs of armed groups, security and economic interests over the needs of the civilian population.

\section{Taming the military}

The strategy of scattering the army throughout the North and South Kivu territory serves the political compromises acquired by the military operations arising different negotiations such as the Goma Accords or the 23 March agreement, and also the purpose of having some form of state authority presence. Despite much criticism of the poor discipline, lack of control and disorganisation of the FARDC, the actions of MONUC/MONUSCO have supported the Government in what seems to be a 'better than nothing' approach. MONUC/MONUSCO, the EU and a plethora of foreign government aid agencies have provided operational support, training and funding (MONUSCO - ISSSS/STAREC liaison Officer 2010; STAREC - Amani Leo Representative 2010). But, aside from militarising the environment, which in practice is a tool for hierarchisation and the reaffirmation of positions of domination, army deployment is also an extractive tool. On a daily basis, the political, social and economic cost of this military 
deployment is assumed by local residents, particularly in rural areas. As seen in previous chapters, this deployment has generated resistance and met with discourses of delegitimisation and armed attacks. The military's dependence on the population has created an ambiguous ground on which survival tactics have been a way both to meet the military's needs and to mitigate its effects. Notwithstanding the abuses of the military, these tactics have subverted the effects of the military presence, such that they serve the self-help logics of the civilian population. Although Chabal, Hibou and Mbembe, for instance, argue that there is not resistance but accommodation, and even a logic of subjection, the dynamics of negotiation highlight that arrangements are contingent, thus allowing for redefining the limits of domination.

In this case, the process of negotiation taps into the logics of reciprocity and creativity that sustain daily life. Militarisation and authoritarianism, imposed by the conditions on which the army is deployed, is 'detotalised' through expectations of mutual obligation and the creation of mutual dependency. On the one hand, FARDC expects the population to respect its authority, provide security intelligence, assume its families' livelihood needs, supply labour and grant it privileges in certain economic exchanges. ${ }^{29}$ On the other hand, residents expect FARDC to provide them with security, policing, labour, a greater guarantee or even 'official' stamp on conflict resolution processes and reciprocity in economic and service exchanges. Judith Verweijen (2013), who has extensively studied civil-military relations, notes that exchanges and civilian expectations of FARDC provision include conflict resolution, arbitration, policing, economic regulation and other governance practices. In terms of conflict resolution, arbitration and policing, these can range from settling chief succession or dowry disputes to being present at football matches and markets and prosecuting crimes such as cattle theft and poisoning (Verweijen 2013). FARDC's authority becomes mitigated and detotalised by the process in which survival, including that of the FARDC troops themselves, is better assured by reciprocity and negotiation than by force. In conditions of arbitrariness and inequality, the sphere of negotiation allows space for equalisation and brings a public eye to precisely the arbitrary and violent use of authority.

This dual effect of creative survival applied to civil-military relations can be seen in the response that the newly deployed battalion of Amani Leo in April 2010 had in Baraka. Arche d'Alliance Refugee Protection Supervisor, Ildefonse Masumbo Zongolo, relates what has been noted by many Baraka and Fizi residents: these troops were forcing the displacement of people just in order to steal their goats to eat, and beating residents sometimes just to steal their mobile phones or money (Masumbo Zongolo 2010) $;^{30}$ some of their members were even accused of rape (Masumbo Zongolo 2010). The worst period, according to Zongolo, was between April and May 2010, which included the attack by Mai Mai Yakotumba in April 2010. Arche d'Alliance organised a series of encounters 
with these troops and with the Amani Leo commandant deployed at Baraka. According to Mr Zongolo, from then on the residents would be able to go to the commandant, tell him who had done what and the commandant would apply the penalty accordingly. In a primary example of how DIY and personal reciprocal ties produce direct control, the victims and their representatives would come to verify whether those who had finally been sentenced were serving their sentence. According to Mr Zongolo (2010):

Now when someone is the victim of misbehaviour by these troops, we visit the Commander and we say: 'call in such and such because he has done so and so' - the Commander applies to him maybe fifteen days of imprisonment ... then we verify whether he is really in the cell ... we go there and may say: 'Commander, we have come to give him something to eat' - each day, because it is necessary that he gets his punishment.

In many ways the hierarchy here has been subverted. This does not change what the military still means for many residents: disorder, violence and abuses, but engaging with it through collaboration, networking, solidarity, exchanges and mutual dependency is a way of equalising the relationship and taming the arbitrariness and authoritarianism of its presence. Jane Jacobs, in her study of public order, argues that order is not kept by the presence of the police, but by the presence of a multitude of bystanders, watchers, wanderers, shoppers, sellers and commuters going ahead with their myriad activities (cited in Scott 1998: 132-46). A similar argument could be made regarding the role of creative survival strategies put in place to host and feed the troops. Their menace, disorder, disruption and distrust are mitigated by the same activities that are used to sustain family, neighbours and community. The hierarchically commanded militarising presence is subverted by making the military dependent, with a duty of reciprocity, on the landscape of 'uninstitutionalized, uncodified habits of streetlevel trust in the production of civic order' (Scott 1999: 280). Forms of mitigation allow for a possible equalising of civil/military relations. Rather than compliance, they signal social conflict and a rejection of militarisation and predation by state authorities.

\section{DIY everything}

As Tollens argues, it is due to the Congolese art of survival and their creative strategies that, in the midst of one of the worst humanitarian catastrophes since the Second World War, there has not been a declared famine (2004: 47). The home-made broom illustrated in Figure 6.1 represents that when something is needed, it is created. This does not apply just to everyday needs but goes as far as peace and reconciliation, mitigation of armed groups' operations and the army presence, and, as this section will illustrate, a variety of social services and 
basic infrastructure. Reciprocity, solidarity and mutual dependencies established through community networks, ethnic, clan or family links, cooperatives and other groups are channels used for survival strategies. Self-reliance takes priority over reliance on the Government or state authorities. Its effect, however, is the subversion of extractive practices and the conditions of poverty and violence inherent in the political order.

As Vlassenroot and Romkena argue:

People tried to rely on the trust of personal relationships to compensate for the absence of a functioning legal and judicial apparatus. They also tried to evade a venal bureaucracy and an oppressive state by operating in the second economy to find opportunities to better lives. This popular economy of survival, in the end, became an alternative system of economic development that completely escaped state control. (2007: 9)

They also note that 'these informal structures can pose a serious constraint to state building as part of reconstruction efforts', and identify three important reasons (Vlassenroot and Romkena 2007: 8). Firstly, this provision undermines legitimacy in the eyes both of the population and of donors. This has a domino effect regarding the alternative channels sought by the population for provision, which include the reliance on armed groups for security provision. Secondly, it places both the population and the state in competition for external funding. Thirdly, as a consequence, donors have felt more legitimate and secure in providing funds to NGOs rather than to the state, which has contributed to an even weaker state presence (Vlassenroot and Romkena 2007: 8-9).

More importantly, these mechanisms of survival entail a deeper political statement that resonates with a logic of re-appropriation over political affairs. They signal a 'reinvention of order', as Trefon (2004a) puts it, where there is a process of negation of the imposed order, a subversion of it and a projection of alternative forms of social organisation and political authority. These points are illustrated with the example of electricity and the case of Mabuku (North Kivu), where there is no permanent presence of state authority.

\section{Household and commercial electricity}

Only 6 per cent of the population in the DRC have access to electricity, although the DRC is an electricity exporter (EU Energy Initiative (EUEI) 2008: 1; Manson 2010). However, Congolese residents access electricity not by demanding it from the Government or the Société Nationale d'Electricité (SNEL), but through selforganising mechanisms. There are three main ways of accessing electricity outside the official provision: by stealing it, by collectively sharing a generator or by paying a fee to a neighbour who has bought a generator. In Kinshasa, people in poor neighbourhoods steal electricity from the official SNEL network. The problem is that this source does not always work. Hence the mockery and 
the renaming of the state electricity provider as the 'National Society of Darkness' ${ }^{31}$ All of the above strategies function to avoid government-provided services and their consequences, including taxes. As an electrician hosting one generator in a neighbourhood in Goma states: 'we don't pay the tax for the electricity anymore because it is not provided, we do it ourselves' (Cooperative Generator Electrician 2010). The fact that for access to electricity it is less trouble and more straightforward to rely on proximity channels and one's own creativity than to engage with the government demonstrates that self-provision is simultaneously a political disengagement from the government.

Strategies to produce household electricity started in the North Kivu territory of Butembo. There, residents started to create a system by which approximately every 60 houses would buy a generator together and set up their own electricity system. The system is basic but orderly, set up with trunks and pieces of wood. One house hosts the generator and everyone contributes to the petrol, and electricity is generated from $6 \mathrm{pm}$ to $10 \mathrm{pm}$. In Figures 6.2 and 6.3 one can observe how a whole electricity system has been created in which lines of cable and wooden posts supply entire neighbourhoods. From Butembo this mean of electricity production has now expanded to other provinces.

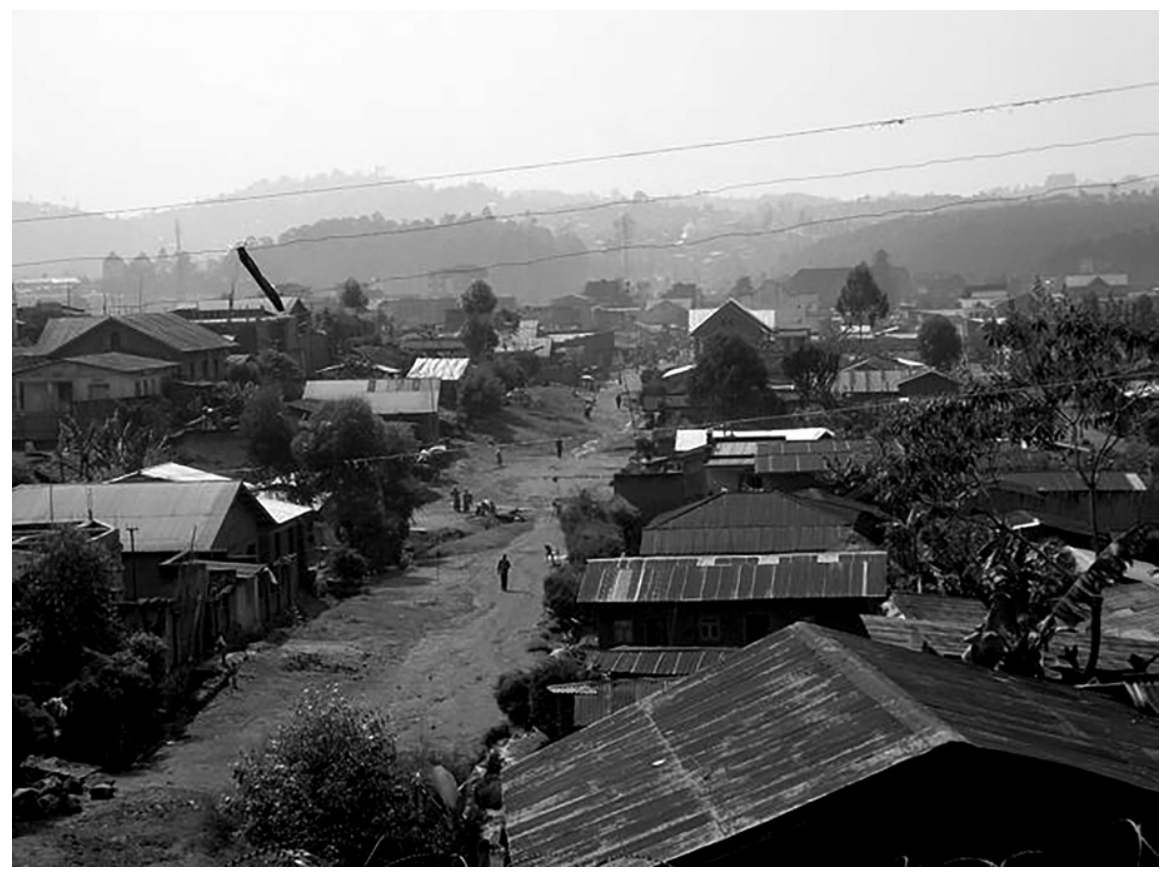

Figure 6.2 Street view with community-built electricity lines, Butembo, photographed 30 July 2010 
Commercial electricity is done generally through an entrepreneur or a collective undertaking within a household to supply the neighbourhood. Those who rent electricity from such an individual or household are generally small businesses such as hairdressers, bars and restaurants or internet cafes. Four households were visited that host a generator in the popular neighbourhood of Keshero, Goma (Figure 6.4). They reported that the cost of the generator around US\$ 3,000 - is never recovered; what users pay for is the cost of running it and the maintenance, although for much of the time this is not enough. Entrepreneurs decide to make the investment because they require electricity for their own business; the fact that they can facilitate the existence of more

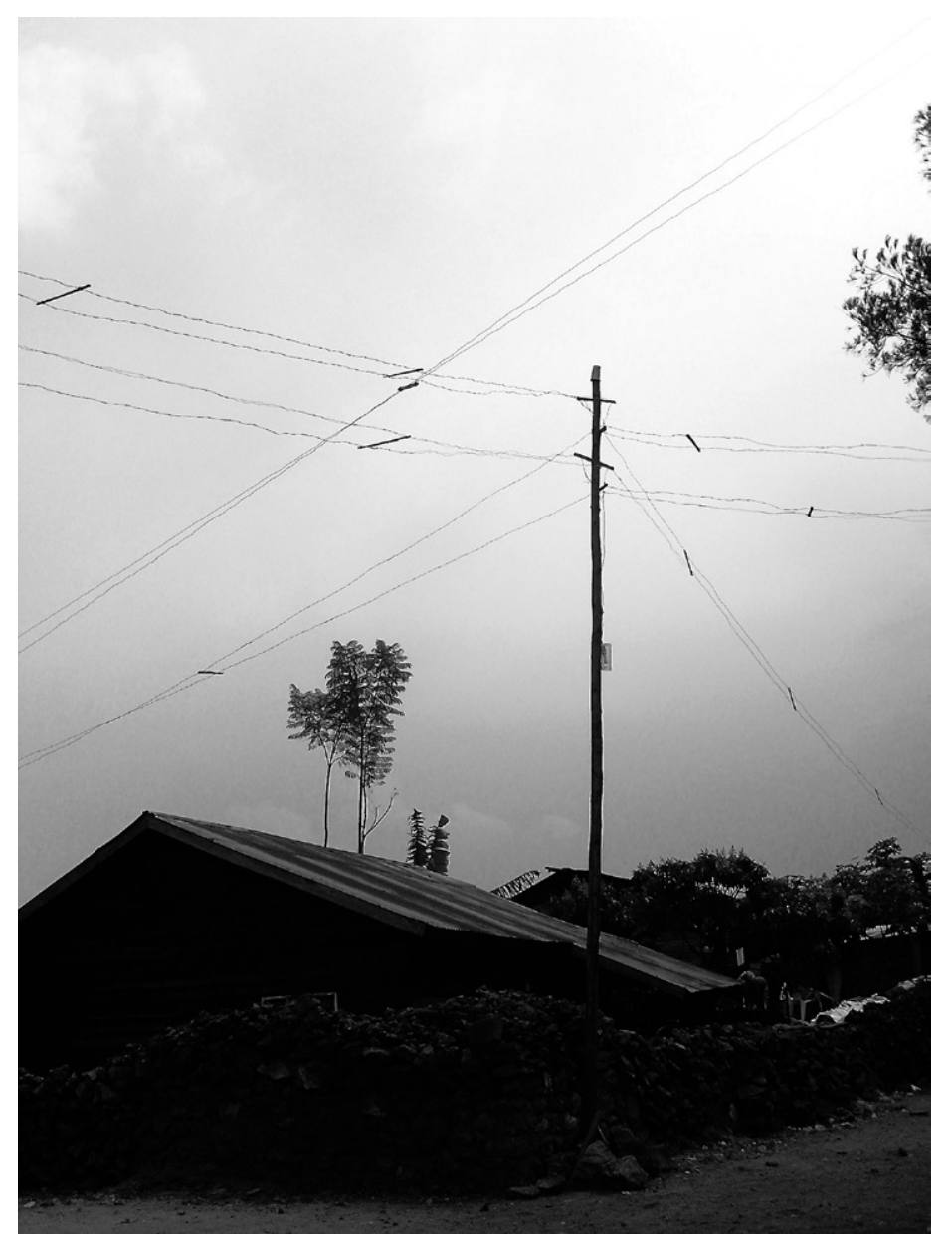

Figure 6.3 Street in Goma, self-made electrical line, photographed 27 July 2010 


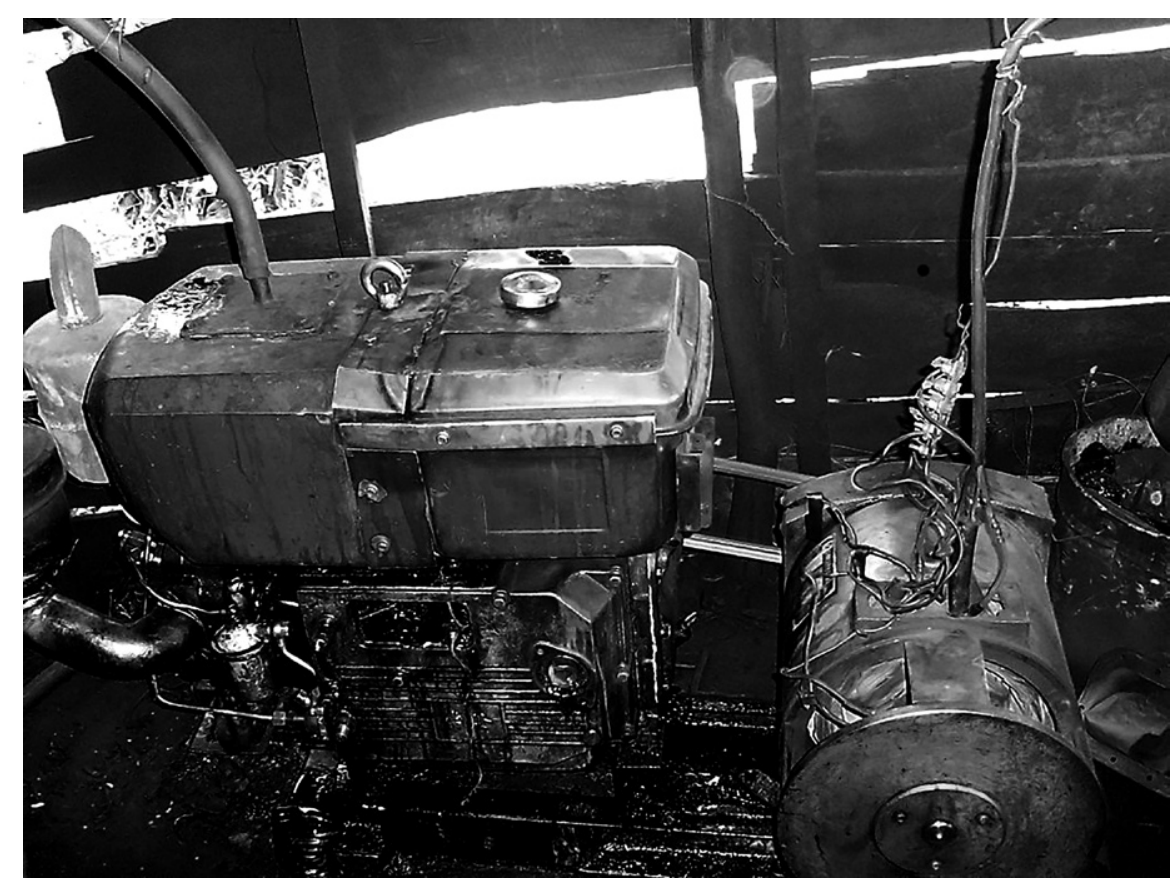

Figure 6.4 Commercial generator, photographed 2 August 2014, Keshero, Goma

businesses offers the neighbourhood more possibilities for development and security (Figure 6.5). The business owners interviewed reported that they paid a fee of between 1,000 and 2,000 Congolese francs per day (US\$1-\$2), which is what they could afford to pay. Other forms of energy production, such as solar panels, are not seen as powerful or easily available. Hence the reliance on these generators.

Commercial electricity provision rests on the same logic of reciprocity and creativity as the household approach. Although it starts from an individual initiative it responds to collective needs and is not for profit. In both examples, the imposed conditions of lack of electricity and lack of interest by the state in providing it are transformed into a logic of provision, collective undertaking and mutual support. Both of these forms of delivering electricity either to the private households or to small businesses generate spaces for dialogue about the production of a public good. This opens collective spaces of mutual support and reciprocity that are simultaneously a space for public organising about an important aspect of the neighbourhood; it avoids state taxes and state enterprises and is able to mitigate the lack of electricity. In these collective spaces, people establish means for distribution and payment. In the case of households, families establish 


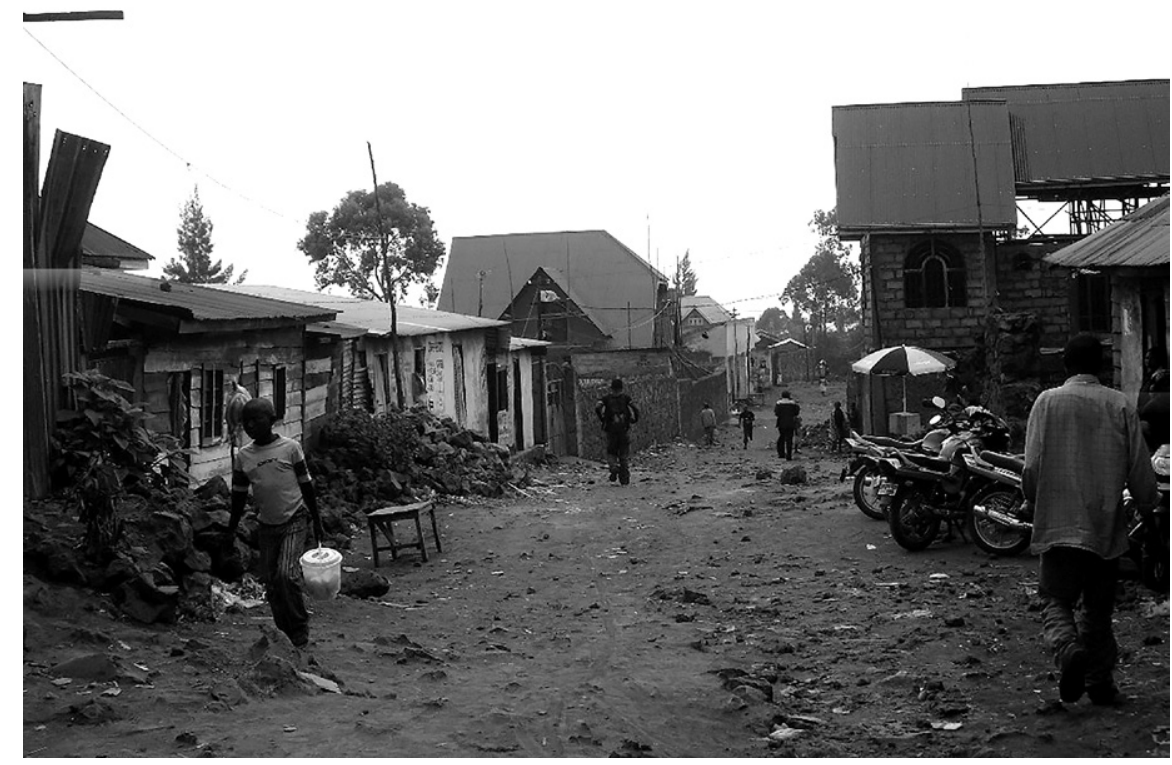

Figure 6.5 Businesses supplied by the generator, photographed 2 August 2014, Keshero, Goma

how much they are going to spend on the generator, how much electricity they are going to use and how the maintenance will be done. In the case of commercial electricity, there is negotiation between the business owners and the generator owner. Although the outcome is the privatisation of electricity, the fact that these mechanisms are very extended has, as a more visible effect, the multiple reproduction of collective spaces of dialogue and decision-making, redefining the terms of the distribution of a public good.

\section{Mabuku 32}

Much of this self-provision is illustrated by the town of Mabuku, a small town in the territory of Beni, North Kivu, where no official authority has a consistent presence. Police, intelligence officers (Agence Nationale de Renseignement) and administrators do not have a permanent post. The Catholic Church, the hospital and a school are the closest forms of institutional authority present, in which the population has a direct input, even in decision-making processes. There is an established payment scheme for teachers, nurses and doctors, who also provide a loose form of authority. For instance, the women of the village built 
the maternity wing of the small hospital/health centre by collecting materials around the area and making their own bricks and renamed it 'Maternite Yetu' (Our Maternity; Figure 6.6). They also established a cooperative so that they can have a partnership with international organisations and thus distribute the money through different activities. ${ }^{33}$ Members of the cooperative receive training, a shovel, a hoe and a machete to work on their fields, and bring their products to the cooperative from different villages nearby in order to trade them. They also contributed money to have a mill for flour.

The cases of Mabuku and of electricity are not isolated: this is the normal way that everyday life is approached across the DRC. Regarding services, others could be added, such as health. Health provision is a paradox because, as Zoë Marriage (2010) has observed, while a substantial amount of aid goes towards health services in DRC, it does not address the causes of the lack of a health service in the first place. Aside from the doctors per population ratio being 0.6 doctors per 1,000 inhabitants, infrastructures are either lacking or in very poor condition (Ngoma and Luzolo 2010; Participant Observation XII 2010; UN Population Fund 2011: 68). Funding comes from a combination of remnants of government health service, INGOs and foreign government aid funding.

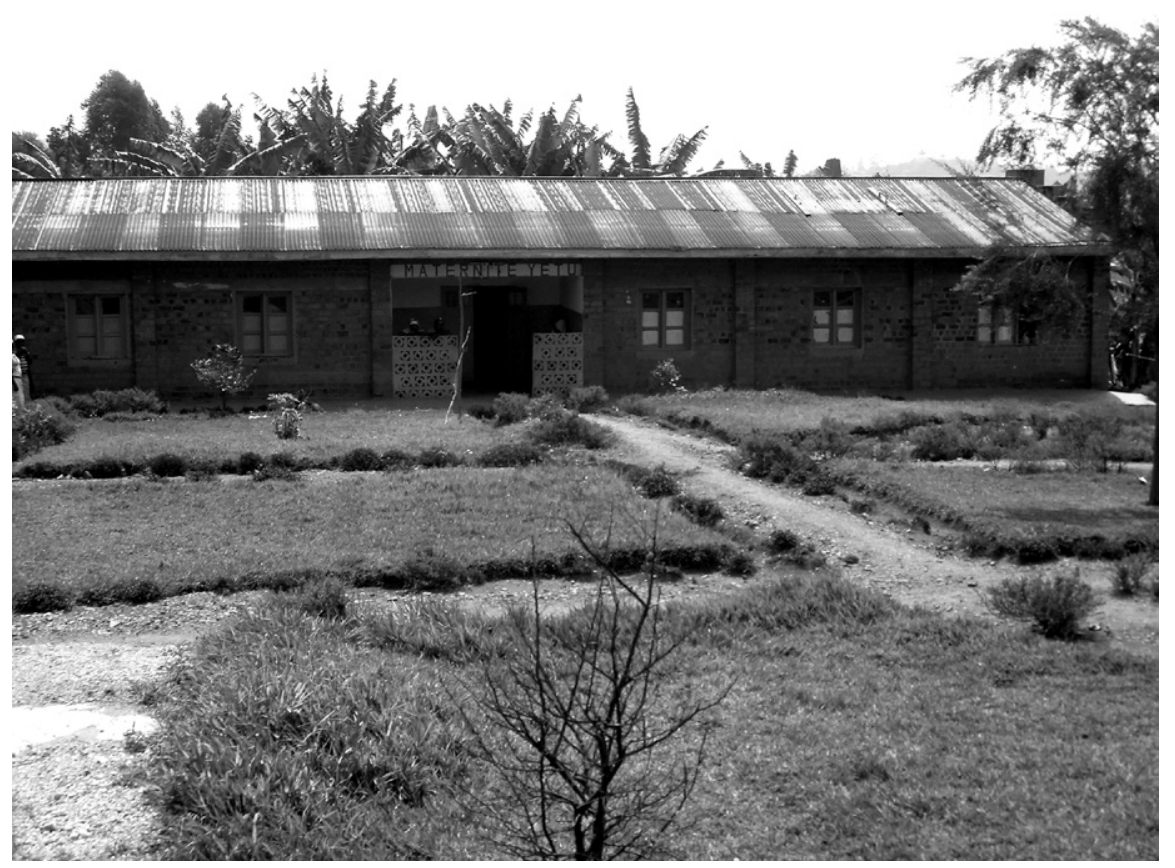

Figure 6.6 Maternity hospital, Mabuku, photographed 1 August 2010 
Patients are asked to pay for the services and if someone does not have money, they can bring a goat so that it can be eaten by those working on the construction site' (Ngoma and Luzolo 2010). The same applies to staff salaries and the provision of medicines. The South Kivu provincial hospital in Bukavu works this way. ${ }^{34}$ State funds are unreliable and insufficient, and its management is done through a Catholic Church scheme, each department being managed on a daily basis by the doctors and nurses working at the hospital, and their ongoing payment relying on the contributions made by the patients (Informal Conversation with Emergency Unit Nurse, South Kivu General Hospital 2010). Similar schemes are found in schools, other social services and in public infrastructure, including road maintenance and house construction.

Infrastructural work is often done through what is called 'Salongo'. Salongo has had several adaptations. It was first a 'perversion of a traditional custom of communal labor in service [...] by colonial administrators to justify forced labor' (Free the Slaves 2011: 13). It was then made 'obligatory civic work' by Mobutu as one-day-a-week work towards community service (Free the Slaves 2011: 13). Under Salongo, FARDC, armed group leaders and government authorities have justified forced labour, including mining, porter services, cooking and housework (Free the Slaves 2011: 13-14). In Butembo, it has been re-appropriated as a way to provide community service and improve living conditions (ADDF 2010; Focus Group Butembo Residents; Neighbourhood Representative of 10 houses 2010; Walikomba 2010). In this case, the beneficiaries of a subverted Salongo are those who initiate these works, and they are also those who need them or otherwise they would not have these services. Other times, people collectively decide not to do Salongo, as is the case in Mwenga, where, despite the call to all residents to do Salongo from 7 am to 10 am on Saturdays, they decided to continue with their own activities. In 2014 the provincial government representative visited Mwenga. People had to clear the roadsides of vegetation but, despite the call by the territorial authorities to do so, people did not attend. Residents argued that it was the work of the roads office to do it and that they already paid the tolls for it to be done (Participant Observation XXVI 2014).

Not only is the extent to which all these important services are provided and to which many more could be added remarkable, but so too is the extent to which this provision creates significant control over important social and political processes. ${ }^{35}$ This does not mean successful evasion of domination, but it does entail resistance to it. As such, these services could be seen, as Mac Gaffey noted of similar dynamics under Mobutu, as a 'political option' against 'the interests of the state-based class' (1987: 157). For Mac Gaffey, this 'political option' was seen as one where 'people confront a predatory state which fails to provide them with the opportunity to earn a living wage, with a functioning economic infrastructure or with basic social services' (1987: 157). These non-confrontational forms of resistance mitigate the effects of domination in which the production of social 
order and decision-making processes are re-appropriated. To retake the language of the MONUSCO officer cited in Chapter 2, taking over these services provides the 'software' that operationalises the 'state'. In this case, such operationalisation is being redirected to serve people's needs, provoking, as Vlassenroot and Romkena argued, the undermining of statebuilding in the process.

\section{Conclusion: reinventing authority}

The illustration at the start of this chapter represents those survival mechanisms that are not only a form of navigating a hostile environment but an activation of multiple channels of exchange and production. These create mutual dependencies resting on solidarity and reciprocity, and have the capacity to subvert the effects of domination. As Aili Mari Tripp states, the provision of and control over these services speak to a broader issue of self-reliance and self-organisation of the social and political arena:

By pursuing their various survival strategies, people were not just responding to necessity, they were actively remoulding their own destinies. They were not only seeking new and innovative ways of obtaining an income, they were consciously and vigorously resisting the state. In the course of defying various anachronistic state policies, they were reshaping the political and economic structures that surrounded them. (2003: 161)

Resistance, then, should be seen in these survival strategies as a mitigation of predation. And this predation is, in the eyes of many people, mainly the responsibility of state action. In the process, as Tripp reminds us, alternative forms of political organisation are being created. In this sense a further argument could be advanced: if, as Mbembe states, Africa has been portrayed as the 'embodiment of nothingness', we might have to rethink Africa as the embodiment of creativity. Survival/DIY activities 'signal renewal and creativity' in ways that show 'Africa [...] immeasurably more alive' (Davidson 1992: 293).

Survival is not just a form of accommodation or domination, but also a form of subversion. Although some survival strategies are a direct denial of a claim, such as evasion of tax levies, they should be seen, following Michel de Certeau, as tactics that, without being intended strategies of attack, and following self-logics and one's own needs, generate the possibility to subvert order. The intent to impose taxes and elite-land distribution is directly rejected through tax evasion, disobedience and multiple strategies to retain landownership and food security, especially through peasant cooperatives. Army deployment provokes a direct impact on the economic and political order. Its maintenance is externalised politically and economically onto the population, making the army dependent on the population. This dependency, alongside subtle negotiating mechanisms, is used by subordinate classes to tame the authoritarian rule of the military and 
its extractive effects. Finally, taking over all sorts of social services and public infrastructure simultaneously provides opportunities for avoiding state control and for establishing forms of social organisation where people participate more directly in decision-making processes. This may not be a 'political threat' as Maliyamkono and Bagachwa point out, 'but they certainly pose an economic challenge to the official establishment' (cited in Mac Gaffey 1991: 157). This challenge has a significant political dimension, since the ways in which state authority is resisted have embedded forms of reinventing social organisation and modes of political authority.

The chapter has addressed one of the pillars of statebuilding: extraction and wealth distribution. Although extraction in the DRC has been seen as statedestructive rather than state-constructive, there is a certain logic to the way in which it is carried out (Johnson and Kayser 2005; Kankwenda 2005). It produces authority: it is not necessarily invested, nor is there a project of turning popular classes into working and consuming taxpayers, but it allows for sectors of the elite to retain channels of appropriation and distribution. It is self-serving: these forms of authority assertion have been examined from the point of view of the effects they have on the civilian population's living conditions. The chapter has indicated three areas of resistance through the dynamics of state presence, the layer of peacebuilding strategies and the dynamics of state absence. These three areas have illustrated patterns of responses and different characteristics of how resistance unfolds.

This challenge is both theoretical and practical. On the one hand, peacebuilding shows itself to be a less peaceful and committed method to building a developed, peaceful, democratic Congo than it claims. On the other hand, it shows that as far as its practice on the ground contradicts subordinate classes' aspirations, it is stripped of legitimacy, attacked and subverted. Mac Ginty's 'tale of two economies' in Iraq, one official and one of survival, reflects how, in the absence of an economy that is able to serve the needs of the population, the people go outside of the official channels, subverting one of the most important foundations of the liberal peace project (2011: 15; ch. 5). In other words, creative survival mechanisms prepare a fertile ground not to accept the state but to reject it.

However, the balance between reciprocities and solidarities, on the one hand, and violence, inequalities and hardships, on the other, demonstrates the ambiguous character of survival. Trefon points out that the reinvention of order in Congo 'has been characterized by tension, conflict, violence and betrayal, as much as by innovative forms of solidarity, networks, commercial accommodation and interdependencies' (2004a: 2). Daily exchanges are the target of scams, deceits and chicanery. But from here important features of resistance can be extracted that relate back to the themes that have been explored in the course of this book.

The analysis of resistance should not project onto the practices used or onto actors the vision of an ethical world that characterises the actors' own 
aspirations. Resistance is contradictory because it is not a permanent state of being of the actors concerned. Nor is it a neat succession of events that connect actors' ideas with their everyday actions and outcomes. On the contrary, seen from the point of view of the actors, resistance is a conditioned response to a particular context and various changing relationships. More so, the ambiguity of survival as a site both of domination and of subversion makes resistance something that cannot be analysed by its strategies, nor by its outcomes. From the point of view of the everyday micro level, resistance rests more on intent, as Scott argued. However, this intent is gradated along a political spectrum that ranges from individual protection against a particular claim, to the collective refusal of it, to the attack against it and the disengagement from it. More important are the patterns created at the macro level by this variety of actions, making resistance a permanent feature of the process of state-making.

\section{Notes}

1 The conditions that represent the particular relationship between sovereignty, life and death in Africa (cf. Mbembe 2003).

2 See Chomsky for an interesting reflection on the role of the state in post-war reconstruction as a vehicle for a capitalist economy (1996: Ch. 2).

3 To say that there is a natural way of surviving poverty resonates with Manfred Max-Neef's observation (1992) that universal strategies against poverty include being alert, creative, imaginative and make use of networks of solidarity and mutual aid. Others have reflected on survival strategies and state-society relations in the DRC (Lemarchand 1989; Mac Gaffey 1991; Roitman 1990).

4 French for 'survival' or 'to get by'. The term makes reference to Mobutu's command in 1973 'débrouillez vous' (fend for yourself), literally meaning that the state was withdrawing many social services. Other terms are also used: 'article 15', 'opération qui cherche', '6e chantier', 'horoscope' and 'libanga' (Yoka 2009: 246).

5 Music is most representative of creativity in the DRC. Not only is it part of Congolese historical heritage in a special manner, but also it is ever present in daily life as an essential part of its recreation. Music has thus particular significance in la débrouille. Arguably, music, even mainstream, is a tool of political engagement rather than simple entertainment (Zeleza and Eyoh 2003: 71 and 130). Note the lyrics of a rumba song by Koffi Olomide: 'Toza na systeme ya lifelo moto ekopela kasi tozo zika te ('We are in hell. The fire is burning, but we don't burn') (cited and translated in Zeleza and Eyoh 2003: 307; see also: Mangwanda 2009).

6 Note here the notion of Jean Marc Ela $(1994 ; 1998)$ whereby the 'Africa at the bottom' has a common project of survival where solidarity is an imperative, an expression of a common cause and an acknowledgement of a common destiny. This is a different notion to that of Göran Hyden's economy of affection (1980), where the peasantry is 'uncaptured' outside the sphere of action of the state by its own survival activities. On the contrary, it is argued, survival is an effect of domination and resistance reflects a social conflict, not non-dominated spheres of action.

7 An exercise against the totalitarian effects of certain forms of authority.

8 'Self' as both individual and collective. 
9 In order to simplify the analysis, the term elite-land appropriation will be used to refer to those strategies that are in the orbit of statebuilding, including as a consequence of the policy to grant ownership to land holders in detriment of collective holdings via customary law, or as the result of new wealth allocations and development policies. The term non-elite land distribution refers to peasants' agendas, which imply collective or customary landownership, land rights and food security.

10 Chabal follows Foucault here. For Foucault, government practice had a certain rationale not only about what government means but about the best way to achieve it. 'Governmental ratio is what will enable a given state to arrive at its maximum being in a considered, reasoned, and calculated way. [To govern is] to arrange things so that the state becomes sturdy and permanent [...] wealthy [and] strong in the face of everything that may destroy it' (Foucault 2008: 4).

11 As Scott argues in relation to inhabitants in the high plateaus of 'Zomia', people do not reject 'development' but domination (2009: 113-15).

12 Callaghy notes that at the time of the copper crisis in 1978, the state had already stopped collecting much of its taxes in a formalised form (Callaghy 2001).

13 Cf. discourses explored in Chapter 5.

14 This interpretation resonates with other studies (Adam and Vlassenroot 2010; earlier studies include: Roitman 1990; Mac Gaffey 1991).

15 Small survey sampling 10 street sellers in the Boulevard Kanyamuhanga in Goma, including: three phone credit sellers, two tomatoes, chillies and peanut sellers, one music seller, three bread sellers and one photocopy maker.

16 Provincial Government of South Kivu, Bukavu's Kadutu neighbourhood. Poster seen on 8 August 2010.

17 This was the tactic used, for instance, by the APR against the Interahamwe, but it has also been used by CNDP and the FDLR (Pillay 2010: para. 150; Andreu Merelles 2008: Facts 18 and 27).

18 This has been the case of the CNDP entering the orbit of Rwanda's state project, and PARECO for the DRC Government to counter it.

19 Other responses include flight and the use of militias. This section explores practices of resistance directly linked to creative survival strategies.

20 For instance, while Banyarwanda Hutu peasants had felt discriminated against by Hunde chiefs in Masisi through at least the beginnings of its largest migration movement from Rwanda in the 1950s, they gained political and military leadership in Masisi by joining the CNDP under Banyarwanda elite and Rwanda's Government (Banyarwanda meaning literally people of Rwanda, which is a term traditionally used in North Kivu to denominate Kinyarwanda speakers, people of Rwandan origin or with Rwandan ancestors). JMAC reports that CNDP was majority Hutu but with minority Tutsi leadership (NRC Representative, 2010; JMAC Officer 3 2012; Vlassenroot 2006).

21 Unless otherwise noted, the information in the following two paragraphs relies on Ngemulo (2010).

22 This is the ethnic community that many members of LOFEPACO belong to. Women are not allowed to own land; when their husband dies, the land is redistributed by the customary chief or through the male members of the family (Ngemulo 2010; Walikomba 2010).

23 Their activities were focused in North Kivu and their name was in fact LOFEPANOKI. After 2005 they acquired a national focus, changing their name to LOFEPACO, although at the time of the interview their radius of action was still North Kivu and more so the Beni-Butembo axis. Maintaining a national coverage, even if nominally, can be a way to have access to certain national and international funding.

24 Information in this paragraph comes from Ngemulo (2010). 


\section{Everyday resistance, peacebuilding and state-making}

25 In particular the INGO Vredesilanden.

26 UCOONAKOPI, LOFEPACO, Association of Manioc producers (Bunyakiri), Syndicat de Protection des Intêrets Paysans (Beni), UPDI and Association Nutrition Assisse Communautaire (ANAC). The first three are federations of cooperatives operating across different territories within the province. UPDI and ANAC also operate as broader platforms for peasants to exchange products and cultivation techniques, provide community service, conduct lobbying activities and attract international funding. UPDI has eight cooperatives associated with five territories in South Kivu (Kabare, Kalehe, Walungu, Mwenga and Uvira), and ANAC works in Mabuku and Beni (North Kivu). This was also the sentiment transmitted in other interviews with peasant unions and producer associations (Market Sellers and Buyers of South Kivu Representative 2010; SPIP Representative 2011).

27 As an example, they stated that 725 hectares of land in Kabiso (North Kivu) that belonged to the cooperative were threatened to be expropriated by the provincial Government. According to a UCOOPANOKI representative, the issue had been taken to court, but 'the approximate 1000 residents were threatened to have to leave in favour of 3 or 4 new proprietors'. Flight normally occurs to another area where other family members can host them, help them to migrate to the city or attempt to work in the mines. Most farms belonging to the cooperative had suffered attacks from all armed groups, in particular, Mweso and Nyanzale (Batenda 2010).

28 Access to just prices was also raised in Bunyakiri by the Manioc Producers Association (Manioc Producers Association Representatives 2010).

29 Respect and intelligence became one of the most important demands of the FARDC to civil society in the MONUSCO Sensitization workshop in Fizi and Baraka to ease civilmilitary relations (Participant Observation XIV 2010). How the civilian population provides for the everyday living needs of the military was directly raised in several interviews. This includes cooking, helping with childcare, aid with housework to military wives or directly hosting them at home (ADDF Representative 2010; FARDC Colonel (no. 129) 2010; FEDI Representative 2010; Femmes Père Saint-Simon Representative 2010; Manioc Producers Association Representatives 2010).

30 The interviewee did not mention that in fact the crimes committed by some FARDC members have amounted to crimes against humanity, condemned in 2011 by a military tribunal in Baraka (UN Secretary General Ban Ki-Moon 2010: para 13, 2011: para. 42).

31 From Société Nationale d'Electricité is called Société Nationale de l'Obscurité.

32 Unless otherwise noted the information relies on Participant Observation I (2010).

33 This included Veterinarios Sin Fronteras (VSF) and Doctors Without Borders.

34 The same staff-patient management either directly or through the mediation of Catholic or Protestant Church schemes was present in Bunyakiri (South Kivu), Butembo and Walikale (North Kivu) and Mbandaka and Gemena (Equateur).

35 Other prominent services include rubbish collection, road repairs and house building (Goma's Town Hall Representative 2010; Participant Observations IV-VII, IX and XXVI). 